University of Nebraska - Lincoln

DigitalCommons@University of Nebraska - Lincoln

Mammalogy Papers: University of Nebraska

State Museum

Museum, University of Nebraska State

8-1-1970

\title{
Taxonomy of the Neotoma albigula-Group of Woodrats in Central Mexico
}

E. Raymond Hall

University of Kansas

Hugh H. Genoways

University of Kansas, h.h.genoways@gmail.com

Follow this and additional works at: https://digitalcommons.unl.edu/museummammalogy

Part of the Zoology Commons

Hall, E. Raymond and Genoways, Hugh H., "Taxonomy of the Neotoma albigula-Group of Woodrats in Central Mexico" (1970). Mammalogy Papers: University of Nebraska State Museum. 44.

https://digitalcommons.unl.edu/museummammalogy/44

This Article is brought to you for free and open access by the Museum, University of Nebraska State at DigitalCommons@University of Nebraska - Lincoln. It has been accepted for inclusion in Mammalogy Papers: University of Nebraska State Museum by an authorized administrator of DigitalCommons@University of Nebraska Lincoln. 


\title{
TAXONOMY OF THE NEOTOMA ALBIGULA-GROUP OF WOODRATS IN CENTRAL MEXICO
}

\author{
E. Raymond Hall and Hugh H. Genoways
}

\begin{abstract}
Study of specimens collected from critical localities since 1944 reveals that: Neotoma montezumae and $N$. leucodon zacatecae are indistinguishable from earlier named taxa; $N$. latifrons is a subspecies of an earlier named taxon; and $N$. palatina, previously known from only one specimen and thought by some mammalogists to be merely an aberrant individual of Neotoma albigula, is a species distinct from $N$. albigula as Goldman tentatively decided when he named it 64 years ago. In the narial passage, the partition formed by the vomer that extends well behind the hard palate as a swordlike projection is present in all specimens of $N$. palatina, but the projection is not present in $N$. albigula.
\end{abstract}

Because of uncertainty about the taxonomic status of woodrats in México for which the names Neotoma latifrons, Neotoma montezumae, Neotoma palatina, and Neotoma leucodon zacatecae had been proposed, specimens that would be expected to be helpful in removing the uncertainty have been saved by collectors from The University of Kansas Museum of Natural History on several occasions in the past 20 years. Our conclusions after studying these specimens and other pertinent materials are set forth below.

Catalogue numbers, unless otherwise indicated, are those in The University of Kansas Museum of Natural History. Measurements are in millimeters.

\section{Neotoma albigula leucodon Merriam}

Comparison of the holotypes and all other available specimens of $N$. $a$. zacatecae Goldman and N. a. leucodon (see list of specimens beyond) permits us to see in specimens used by Goldman (1910:38) all but one of the cranial features relied on by him to differentiate between the two subspecies. The one feature not seen is the greater arching across the anterior roots of the zygomata in zacatecae. The other cranial features relied on by Goldman are seen to be individual variations now that many more specimens than he had in 1910 are available to us. These features are decurved rostrum, longer frontals, heavier maxillary arm of the zygoma, and smaller upper incisors. The dusky instead of grayish or whitish upper lip thought by Goldman (loc. cit.) to distinguish zacatecae from leucodon does not do so in five specimens of zacatecae from $13 \mathrm{mi}$. N Jalpa, Zacatecas; the upper lips of four are dusky and in one white. Neither does the darker color of back and sides ascribed to zacatecae by Goldman (loc. cit.) appear to be distinctive when taking variation with season and age into account. For example, two of five adults of leucodon from $2 \mathrm{mi}$. ESE Trancoso are as dark as four of five specimens of zacatecae from $13 \mathrm{mi}$. N Jalpa (only 15 miles south of the type locality of zacatecae). Furthermore, a specimen from $3 \mathrm{mi}$. SW Jalpa is as pale as the palest specimen (36875) of leucodon available to us. 
Baker and Greer (1962:126-127) referred eight specimens from southwestern Durango to N. a. zacatecae because of the dark color of three specimens from the Guadian lava field. One of the three (49595, from $1 \mathrm{mi}$. N Charro) is the darkest available to us of zacatecae and leucodon but its color is what would be expected of a woodrat living on dark lava. Two other specimens (49596 and 49597 from $15 \mathrm{mi}$. S and $29 \mathrm{mi}$. E Durango) are indistinguishable from normal individuals of leucodon. A fourth specimen (63078 from $9 \mathrm{mi}$. N Durango) is paler than many specimens of leucodon. We have not seen the other four specimens (one from $4 \mathrm{mi}$. S Morcillo, one from $5 \mathrm{mi}$. S Durango, and two from $16 \mathrm{mi}$. S and $29 \mathrm{mi}$. W Vicente Guerrero), but they are paler than those we have examined according to Baker and Greer (op. cit.).

Results of the comparison of specimens lead us to regard N. a. zacatecae as indistinguishable from the earlier named $N$. a. leucodon.

Goldman named Neotoma montezumae in 1905 on the basis of an adult male (the holotype), a young male, a young female, and possibly a fourth specimen not seen by us, all from Zimapán, Hidalgo, as well as a juvenal female from nearby Ixmiquilpan. Although N. montezumae has long been regarded as more closely allied to the species Neotoma albigula than to any other species, montezumae until now has stood as a monotypic species. For some unaccountable reason Goldman in his original description in 1905 and in his revision in 1910 compared montezumae only with the geographically remote Neotoma albigula melanura of Sonora and Chihuahua, instead of with the intervening subspecies N. a. leucodon and N. a. albigula. His key (1910:17) bracketing montezumae with melanura on the basis of the fur on the throat and chest being more or less plumbeous basally did not agree with his description (1910:41) of montezumae wherein he correctly noted that the fur on the throat and chest is "pure white" and not plumbeous at the base. Noting other characteristics of the species Goldman (1910:42) stated: "The skull [of montezumae] shows a slight departure from the albigula type in the depth of the anterointernal re-entrant angle of the first upper molar."

On 23 and 24 September 1964, Percy L. Clifton collected an adult female and juvenal male at a place $7 \mathrm{mi}$. SW Huichapan, $7200 \mathrm{ft}$., a young female at Ixmiquilpan, $5550 \mathrm{ft}$., and a subadult female $7^{1 / 2} \mathrm{mi}$. WSW Ixmiquilpan, 6200 $\mathrm{ft}$. His search was unproductive at that time for other specimens and populations that might link montezumae with $N$. albigula leucodon, in the region farther to the west in Querétaro and for many miles to the south in the state of México. In fact he did not find any sign or especially suitable habitat for Neotoma, probably due to man's long-continued abuse of the land in this region. In 1896, Nelson and Goldman obtained an old male and subadult female at Marqués, Hidalgo, approximately 40 miles south of Zimapán; these specimens were referred to Neotoma albigula leucodon by Goldman (1910:37).

Careful comparison of the specimens mentioned above and the other specimens in the U. S. National Museum and The University of Kansas Museum of Natural History discloses some interesting facts. The deep re-entrant angle 
on the occlusal surface of the first upper molar of the holotype of montezumae is absent in all other specimens assignable on geographic grounds to montezumae but appears in some individuals of leucodon (for example, 105855 from $3 \mathrm{mi}$. E Totatiche, Jalisco). The angle in the holotype is narrow but deep. The considerable depth results from the tooth having been worn down to a level at which the angle probably was deepest. In the specimens of montezumae (labeled with reference to Huichapan, Zimapán, and Ixmiquilpan) the only feature that might be thought to differentiate them, as a taxon, from $N$. $a$. leucodon is narrower skull in adult males. The holotype is the only adult male available of montezumae and its skull is narrower than that of the adult male holotype of leucodon and the likewise broad skull of the old male from Marqués, but in two other old males of leucodon (from Lagos, Jalisco) the skull of one (USNM 78991) is even narrower than that of montezumae and the skull of the other (USNM 78992) is as broad as the one from Marqués. Consequently, it seems that the holotype of montezumae is merely an individual variant of leucodon, not an extreme variant in as much as its interpterygoid space, incisive foramina, and nasals are not so narrow (relative to length of skull) as are the corresponding parts in USNM 78991 from Lagos. We conclude that Neotoma montezumae Goldman, 1905, is properly arranged as a synonym of Neotoma leucodon Merriam 1894 [= Neotoma albigula leucodon Merriam].

Specimens examined of Neotoma albigula leucodon (states and localities within each state are listed from north to south), 113 as follows.-Durango: Hda. Atotonilco, 6680 $\mathrm{ft}$., 1 ; $1 \mathrm{mi}$. N Charro, $6450 \mathrm{ft}$., 1; $9 \mathrm{mi}$. N Durango, $6200 \mathrm{ft}$., 1; $15 \mathrm{mi}$. S, $29 \mathrm{mi}$. E Durango, $5700 \mathrm{ft}$., 2. Zacatecas: Concepción del Oro, $7680 \mathrm{ft}$., 1; $15 \mathrm{mi}$. S Concepción del Oro, $6900 \mathrm{ft}$., 1; $1 \mathrm{mi}$. SW San Tiburcio, $7000 \mathrm{ft}$., 6; $8 \mathrm{mi}$. S Majoma, $7700 \mathrm{ft}$., 6; Villa de Cos, $6700 \mathrm{ft}$., 6; $10 \mathrm{mi}$. N Zacatecas, $6200 \mathrm{ft}$., 1; Valaparíso, 5 (USNM); 8 mi. SE Zacatecas, $7225 \mathrm{ft}$., 2; $2 \mathrm{mi}$. ESE Trancoso, $7000 \mathrm{ft}$., 7; Plateado, 1 (USNM, holotype of zacatecae); $13 \mathrm{mi}$. N Jalpa, $5000 \mathrm{ft}$., 6; $3 \mathrm{mi}$. SW Jalpa, $4600 \mathrm{ft}$., 1. SAn Luis Potosí: $8 \mathrm{mi}$. SW Ramos, $6700 \mathrm{ft}$., 3; $10 \mathrm{mi}$. NE San Luis Potosí, $6000 \mathrm{ft}$., 3; San Luis Potosí, 1 (USNM, the holotype of leucodon). JALisco: $1 \mathrm{mi}$. S Huejúcar, $5850 \mathrm{ft}$., 7; La Mesa Maria de León, $7400 \mathrm{ft}$. (about $22^{\circ} 25^{\prime} \mathrm{N}, 103^{\circ} 24^{\prime} \mathrm{W}$ ), 5; $3 \mathrm{mi}$. S Huejúcar, $5900 \mathrm{ft}$., 3; $3 \mathrm{mi}$. E Totatiche, 5600 ft., 17; 10 mi. NW Matanzas, $8000 \mathrm{ft}$., 5; Belen de Refugio, $5700 \mathrm{ft}$., 1; Lagos, 2 (USNM); $10 \mathrm{mi}$. NE Yahualica, 1; $14 \mathrm{mi}$. SE Lagos de Moreno, $6700 \mathrm{ft}$., 2; $3 \mathrm{mi}$. E Unión de San Antonio, $6100 \mathrm{ft}$., 1. Aguascalientes: $4 \mathrm{mi}$. WSW Aguascalientes, $6100 \mathrm{ft}$., 2 . Guanajuato: La Quemada, 1 (USNM). Queretaro: Tequisquiapam, $6500 \mathrm{ft}$., 1 (USNM). Hidalgo: Zimapan, $6200 \mathrm{ft}$., 3 (USNM, including holotype of montezumae); Ixmiquilpan, $6000 \mathrm{ft}$., 1 (USNM); Ixmiquilpan, $5500 \mathrm{ft}$., 1; 71/2 mi. WSW Ixmiquilpan, $6200 \mathrm{ft}$., $1 ; 7 \mathrm{mi}$. SW Huichapan, $7200 \mathrm{ft}$., 2; Marqués, 2 (USNM).

\section{Neotoma albigula latifrons Merriam}

Merriam in his original description (1894:121), and Goldman (1910:38-39, pl. II, figs. 5 and $5 \mathrm{a}$ ) when he revised the genus, had available only one specimen, the holotype, of latifrons. Goldman (loc. cit.) arranged it as a species but noted that it "is rather closely related to N. a. leucodon and may intergrade with it in southern Guanajuato." 
TABLE 1.-Means and extremes (in parentheses) of measurements of adults of two subspecies of Neotoma albigula. The specimens of latifrons are from Isla Palmitas, Michoacán, and those of leucodon are from various localities in the states of Jalisco, San Luis Potosí, México, and Zacatecas. Cranial measurements were taken as described by Goldman (1910:12).

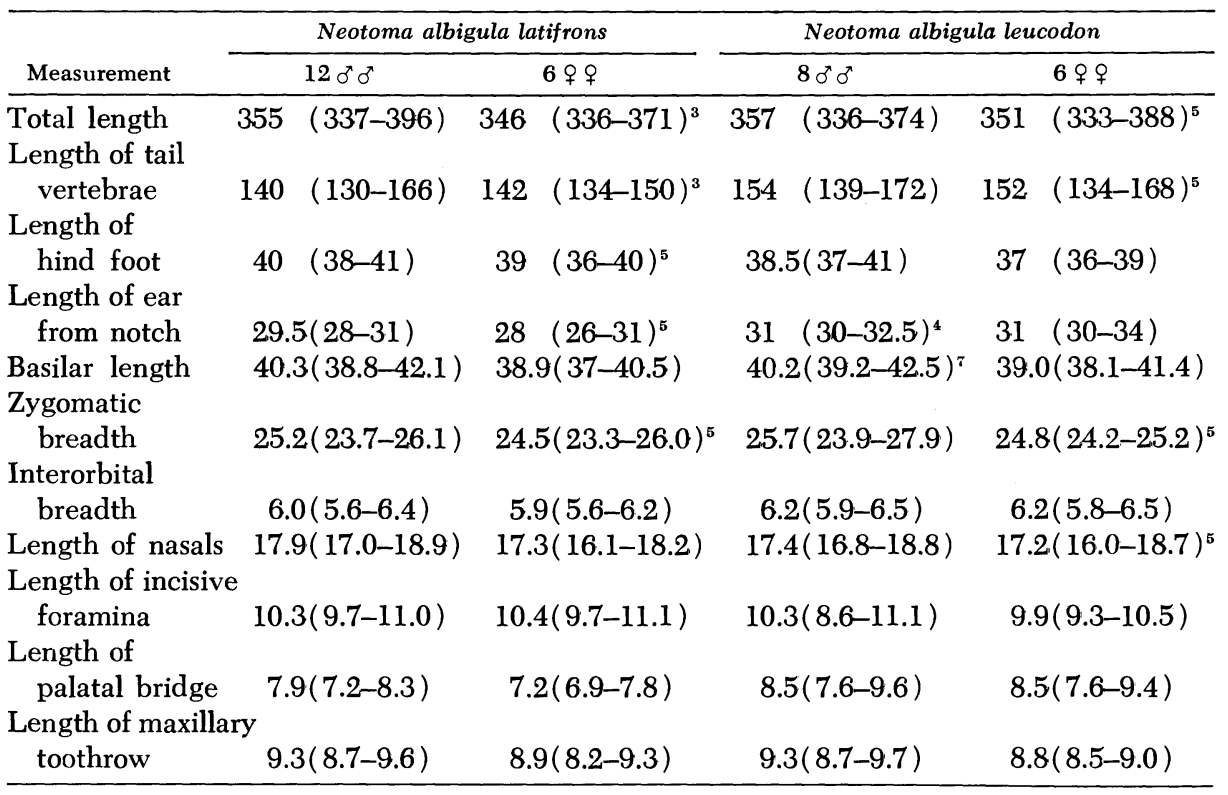

Superscript numbers indicate number of specimens averaged when less than figure given at top of column.

From 15 through 19 June 1967, Percy L. Clifton sought specimens in southern Guanajuato and northern Michoacán that would permit meaningful comment on the taxonomic status of "Neotoma latifrons." His field notes for 1967 read: "June 18. After asking many natives about packrats we have come to the conclusion that there haven't been any Neotoma here for several years but that there were several years ago. ... Finally a man told us the only place he had ever seen them was on an island in Lake 'Cuitzeo.' So, we drove to Estación Queréndaro, $6200 \mathrm{ft}$., Michoacán, which is a small fishing village and train station at the south edge of Lago de Cuitzeo. There are several islands in the lake but some local fishermen thought that an island called 'Palmitas' would be the easiest island to catch rats on. They say there are some albino [individuals of] Neotoma on one of the other islands but that they are getting real scarce. We paid several fishermen to help us catch rats. In a half hour we arrived at the island; in another hour and [a] half we had 21 [specimens of] Neotoma. There . . . is a great abundance of nests [= houses] on the ground in thorn bushes and nopal cactus.... I found no fleas on the rats. We found no babies in the nests and no embryos in the females caught." On the following day Clifton searched the area $4 \mathrm{mi}$. E Acambara, Guanajuato, and between there and Cuidad Hidalgo, without finding any sign of woodrats and without obtaining specimens in traps set overnight in the area. 
All specimens ( 12 males, six females) preserved from Isla Palmitas are adults (almost old) and those of a given sex show little individual variation. The holotype of latifrons, from Queréndaro, approximately $20 \mathrm{~km} \mathrm{~S}$ Isla Palmitas, is a male, barely adult, and therefore younger by at least some months than the males from Isla Palmitas. The holotype differs from the 12 older males from the island in having more reddish pelage, except that new, incoming pelage of the holotype (on the top of the head from half way between the eyes and ears anteriorly) is indistinguishable from that of 112370 from the island. The reddish cast of the remainder of the pelage of the holotype (obtained on 8 August 1892) is attributable to wear and fading in life and possibly to foxing in the course of the 75 years it has been a study specimen. Other features in which the holotype differs from the insular males are as follows: more widely separated temporal ridges that continue anteriorly as supraorbital shelves; broader across frontal region and palatine bones immediately behind third upper molars; shorter skull, nasals, and anterior palatine foramina. Each of these differences in principal part, and possibly entirely, is owing to the lesser age of the holotype. Older specimens (topotypes) from the mainland or younger specimens from the island are desirable, of course, in order to make certain that the difference in ontogenetic age accounts for the differences just mentioned. One difference distinguishing the holotype of latifrons from all specimens from Isla Palmitas is the more posterior position of the posterior margin of the hard palate in relation to the last upper molars. We think this is not to be accounted for by difference in age of the specimens. The broader interpterygoid space in the holotype also may be in the same category. Both of these features conceivably are individual variations, but on the other hand may be uniformly present in the mainland population. In that event, separate taxonomic recognition of the population on Isla Palmitas would be indicated. Therefore, it is appealing to speculate about some of the difference being due to isolation, and to hope that someone will obtain an adequate sample from each of the islands mentioned by Clifton. In any event, when and if there is an increase in the population of woodrats on the mainland, another effort should be made to obtain topotypes of Neotoma latifrons.

Several features of the specimens under consideration clearly place them in the Neotoma albigula species-group. In details of the skull, the holotype from Queréndaro and the skulls of specimens from Isla Palmitas resemble each other more than either sample resembles any other population of the species $N$. albigula. For the present, therefore, we may speak of both lots as referable to Neotoma latifrons. As a taxon it is characterized by prominent supraorbital shelves, frequently with a "nubbin" at the union of the supraorbital and temporal sections of each shelf, and in comparison with $N$. a. leucodon has a narrower skull with a shorter palatal bridge, and a proportionately shorter tail ( Table 1).

Many more study specimens of Neotoma albigula are available now than was the case 60 years ago when Goldman made his revisionary study. Our 

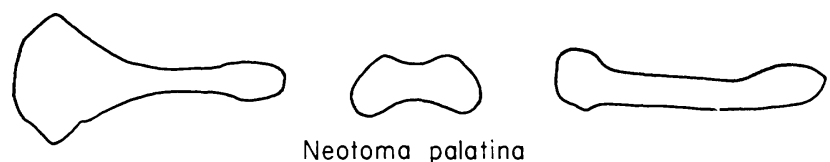

Neotoma palatina
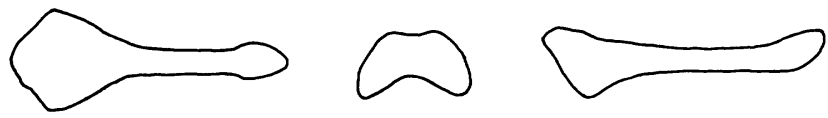

Neotoma albigula leucodon
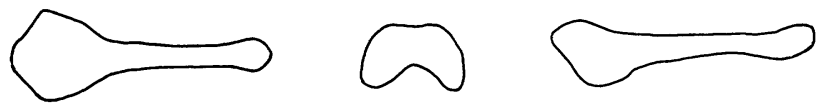

Neotoma albigula latifrons

$2 \mathrm{~mm}$

Fic. 1.-Bacula, in dorsal, lateral, and proximal views of three kinds of woodrats: top, Neotoma palatina (107817, $1 \mathrm{mi}$. NW Mezquitic, $5000 \mathrm{ft}$., Jalisco); middle, Neotoma albigula leucodon (99021, $13 \mathrm{mi}$. N Jalpa, $5000 \mathrm{ft}$., Zacatecas); bottom, Neotoma albigula latifrons (112374, Isla Palmitas, Lago Cuitzeo, $6200 \mathrm{ft}$., Michoacán).

examination of the available material reveals that the prominent supraorbital shelves appear in certain specimens of Neotoma albigula leucodon, geographically adjacent to latifrons on the north and east. For example, the shelves are present, even if slightly less prominent, in 58617, a young female from $1 \mathrm{mi}$. SW San Tiburico, $7000 \mathrm{ft}$., and 58622, an adult female, from $8 \mathrm{mi}$. S Majoma, both in Zacatecas. The occurrence of these supraorbital shelves in leucodon, although they are not so prominent as in latifrons, suggests close relationship of the two and that the two taxa may intergrade in southern Guanajuato as Goldman suggested. Also, examination of the baculum of two specimens of latifrons reveals that the morphology of this structure is essentially the same as that of leucodon (Fig. 1). The measurements of the bacula, length 7.4, 6.3, and width of base 2.6, 2.7, fall within the range found by Burt (1960:60) for N. albigula, length 5.9 to 7.4 and width of base 2.6 to 3.4 .

On the basis of the evidence available to us, we feel that this taxon should stand as Neotoma albigula latifrons. However, proof that intergradation occurs between latifrons and leucodon is lacking. Therefore, when specimens from critical localities become available, the taxonomic relationship of the two kinds of woodrats should be reinvestigated. Moreover, the specimens from Isla Palmitas raise the additional question of whether the name latifrons as we have used it is composite by virtue of our applying it both to the mainland population and the insular population in Lake Cuitzeo. 


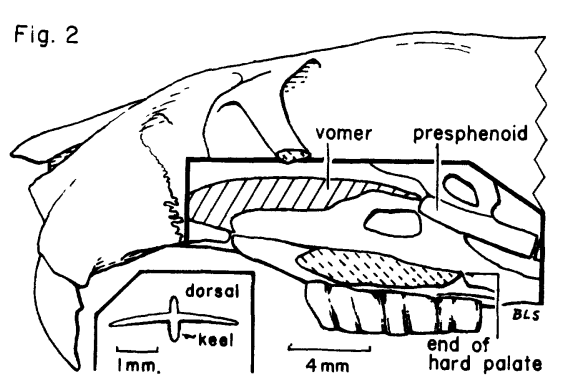

Neotoma albigula leucodon

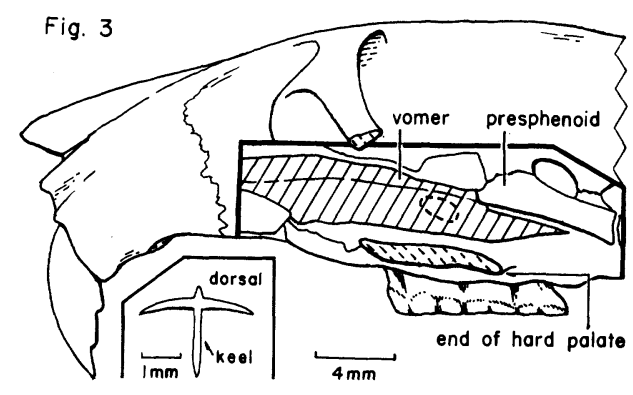

Neotoma palatina

FIgs. 2-3.- Vomer bone in two species of woodrats: Neotoma albigula leucodon, KU 105854 ad., 3 mi. E Totatiche, 5600 ft., Jalisco; Neotoma palatina, KU 99038 ad., 6 mi. NE Bolaños, Jalisco. Slightly diagramatic representation of bones in a sagittal section (enclosed by heavy black line) of the skull of two species showing posterior extent of vomer (diagonal lines), with transverse section of vomer above posterior margin of M2 at lower left. Areas with broken lines denote cut or broken surfaces of bones.

\section{Neotoma palatina Goldman}

On 12 September 1897, Nelson and Goldman obtained a woodrat at Bolaños, Jalisco, and in 1905 Goldman (p. 27) designated it as the holotype of a new species for which he proposed the name Neotoma palatina. In the revision by Goldman (1910:40-41, pl. 3, Fig. 1) he adequately described the specimen, figured the skull (exactly natural size), and wrote: "vomer prolonged posteriorly as a thin vertical plate along median line of presphenoid, partially dividing posterior nares and ending in a point at suture between presphenoid and basisphenoid. ... This remarkable animal appears to be an aberrant member of the albigula group. ... The posterior prolongation of the vomer . . . is a unique character."

Until now the holotype is the only specimen reported. Considering that it was captured less than 70 miles southwest of the geographic range of the widely distributed Neotoma albigula (see Hall and Kelson, 1959:687), some mammalogists, including ourselves, had speculated that the specimen was only an abnormal individual of Neotoma albigula. Nevertheless, study of the 55 specimens from 12 localities listed below, mostly collected by Percy L. Clifton, show Goldman's decision to accord specific rank to Neotoma palatina to have been correct.

There is no suggestion of intergradation between N. palatina and N. albigula leucodon in any of the specimens examined (see Fig. 4 for geographic ranges). In a stone fence at a place $3 \mathrm{mi}$. E Totatiche, Jalisco, 17 specimens typical of $N$. a. leucodon and one typical of $N$. palatina were collected. Three specimens from $5 \mathrm{mi}$. NE Huejuquilla, Jalisco, and one from $10 \mathrm{mi}$. NE Huejuquilla, are $N$. palatina, whereas five specimens from Valparaíso, Zacatecas, only $81 \frac{1}{2}$ miles to the northeast, are N.a. leucodon. The distribution of N. palatina is confined 
to the barranca of Río Bolaños, its tributaries, and immediately adjacent uplands. In this area N. a. leucodon occurs in upland situations and it is there and along the small tributaries that the ranges of the two species geographically approach each other and in the one case meet or possibly overlap.

In Neotoma albigula the vomer extends posteriorly to the anterior end of the presphenoid and no farther. On the anterior part of the vomer a keel drops as far as the floor of the narial passage, creating paired nasal passages all the way back to the posterior end of the premaxillary process that separates the two anterior palatine foramina one from the other. At that point the keel becomes abruptly shallower, and posteriorly disappears well short of the posterior end of the presphenoid (see Fig. 2). A transverse cut through the narial passage between the second upper molars of an adult male $N$. a. albigula (USNM 265007) from Tucson, Arizona, reveals no trace of a longitudinal septum, soft tissue, bony tissue, or cartilaginous tissue. In Neotoma palatina, the deepest part of the keel continues posteriorly past the sutural union of the premaxillary- and maxillary-processes and separates the anterior palatine foramina. Posteriorly the keel is only slightly shallower, and it separates the dorsal half to two-thirds of the narial passage all the way to the anterior end of the presphenoid (see Fig. 3). Instead of terminating there, the keel, shaped like the blade of a hunting knife, although unattached to either the roof or floor of the narial passage, extends back approximately to the end of the hard palate, and in some individuals even farther, usually having a bayonetlike process (not in 99038) terminating near the suture between the presphenoid and basioccipital. The termination varies from individual to individual being anywhere from 2.2 behind to 2.7 in front of the suture. By peering obliquely through the anterior palatine foramina a person can see the deep keel extending from roof to floor in the narial passage of palatina, and the shallow keel extending only one-third of the way to the floor in albigula, at the anterior end of the maxillary process.

$N$. palatina differs further from $N$. albigula leucodon in cranial features as follows: narrower sphenopalatine vacuities; large aperature, instead of small aperature (or none at all) in albigula, where the pterygoid bone joins the palatal bone; wider interpterygoid space; and less inflated tympanic bullae in most specimens. Goldman (1910:27-28) pointed out these differences, but thought the sphenopalatine vacuities in the holotype of palatina were "completely closed by the palatines." Close inspection of our specimens reveals these vacuities in every individual, and we think moistening and then removing the membranous tissue still adhering to the skull of the holotype will reveal that it too has narrow vacuities. For measurements of this species, see Table 2.

The measurements and morphology of the baculum of the two species are different (Fig. 1); in six adults of palatina the baculum averages longer 7.1 (6.6 to 7.5) and broader across the base 3.4 (3.25 to 3.8) than in 13 specimens of albigula listed by Burt (1960:60) (length 6.1, 5.9 to 7.4; width 2.9, 2.6 to 3.4). In lateral view, the configuration of the bases of the bacula of the two species 
TABLE 2.-Means and extremes (in parentheses) of measurements of Neotoma palatina. The specimens are from localities, in Jalisco, recorded with reference to Bolaños and Villa Guerrero. Cranial measurements were taken as described by Goldman (1910:12).

\begin{tabular}{lcccc}
\hline \multicolumn{1}{c}{ Measurement } & 2 Old $\sigma^{\circ} \sigma^{\circ}$ & 6 Adult $\sigma^{\circ} \sigma^{\circ}$ & 6 Adult $\%$ \\
\hline Total length & 374,350 & $368(333-404)$ & $350(326-378)$ \\
Length of tail vertebrae & 161,139 & $162(145-180)$ & $157(144-171)$ \\
Length of hind foot & 37,39 & $37(36.0-38.5)$ & $35.5(34.0-37.0)$ \\
Length of ear from notch & $31,30.5$ & $30(28-32)$ & $30(28.5-32)$ \\
Basilar length & $42.8,39.5$ & $38.8(37.5-40.5)$ & $37.7(36.5-38.9)$ \\
Zygomatic breadth & $25.7,25.9$ & $24.7(23.2-26.0)$ & $23.7(23.1-24.6)$ \\
Interorbital breadth & $6.0,6.3$ & $5.8(5.5-6.1)$ & $5.7(5.4-6.0)$ \\
Length of nasals &,-- & $16.9(16.0-17.9)$ & $16.8(16.2-17.5)$ \\
Length of incisive foramina & $11.0,10.2$ & $10.2(9.4-10.8)$ & $9.9(9.4-10.3)$ \\
Length of palatal bridge & $7.9,7.3$ & $7.5(7.2-7.8)$ & $7.2(6.9-7.8)$ \\
Length of maxillary toothrow & $9.1,8.6$ & $9.2(8.8-9.5)$ & $8.9(8.3-9.3)$ \\
\hline
\end{tabular}

differ, and in a view of the proximal end, the baculum of palatina is seen to be more deeply notched dorsally than is the baculum of albigula.

Although N.a. leucodon and N. palatina closely resemble each other in color of pelage, palatina has less ochraceous buff on the sides and most specimens have less on the back as can be seen when specimens of leucodon and palatina of the same age and stage of pelage, taken at the same time, are compared.

Specimens examined of Neotoma palatina (all from Jalisco, arranged by locality from north to south ), 55 as follows. $-10 \mathrm{mi}$. NE Huejuquilla, $6800 \mathrm{ft}$., $1 ; 5 \mathrm{mi}$. NE Huejuquilla, $6200 \mathrm{ft}$., 3; $1 \mathrm{mi}$. NW Mezquitic, $5000 \mathrm{ft}$., 4; $3 \mathrm{mi}$. N Villa Guerrero, $5600 \mathrm{ft}$., 16; 41/2 mi. W Villa Guerrero, $5200 \mathrm{ft}$., 1; $4 \mathrm{mi}$. W Villa Guerrero, $5500 \mathrm{ft}$., $3 ; 3 \mathrm{mi}$. E Totatiche, 5600 $\mathrm{ft}$., 1; $6 \mathrm{mi}$. ENE Bolaños, $5350 \mathrm{ft}$., 10; $4 \mathrm{mi}$. ENE Bolaños, $4400 \mathrm{ft} ., 1 ; 2 \mathrm{mi}$. E Bolaños, $3550 \mathrm{ft}$., 6 ; 1 mi. E. Bolaños, 3350 ft., 6; Bolaños, 3 ( KU 2, USNM 1).

\section{Recognized Kinds of Neotoma albigula-Group of Woodrats}

Geographic ranges are shown on the map (Fig. 4). Unless listed below, marginal localities (those in italics not plotted on the map), type localities, citations to places and dates of publication of names, and first uses of current name-combinations are to be found in "The Mammals of North America" by Hall and Kelson (1959:686-689). Numbers 1 to 18 correspond to the same numbers on Fig. 4.

1. Neotoma albigula albigula Hartley, 1894 (synonym, Neotoma intermedia angusticeps Merriam, 1894). Marginal Records (Hall and Kelson, 1959:686, unless otherwise noted).New Mexico: Chama Canyon; Rinconado; $25 \mathrm{mi}$. SW Tucumcari. Texas: Washburn; Armstrong Co.; 6 mi. SSE Lazare (Dalquest, 1968:19); Llano; Black Gap region, Brewster Co.; The Basin, Chisos Mts., $5200 \mathrm{ft}$. Coahuila: Fortín, $3300 \mathrm{ft}$; Monclova; Jaral; Jimulco. Durango (Baker and Greer, 1962:126): San Juan, $10 \mathrm{mi}$. WSW Lerdo; Mapimí; $7 \mathrm{mi}$. NW Conejos, $4100 \mathrm{ft}$; $6 \mathrm{mi}$. E Zavalza, $4150 \mathrm{ft}$. Chihuahua: Santa Rosalía; Santa Eulalia. Sonora: Hermosillo. Arizona: Nogales. Sonora: Santo Domingo. Arizona (Cockrum, 1961: 191-194): Papago Well; 9 mi. E Papago Well; E base Crater Mt., 13 mi. N Ajo, $1200 \mathrm{ft}$; Gila Bend; near Buckeye; Wickenburg, $2500 \mathrm{ft}$.; Congress Junction; Big Sandy Creek; Hualpai Mts., 5800 ft.; Kingman, 3300 ft.; Gold Basin, $3000 \mathrm{ft}$.; Peach Spring, $4000 \mathrm{ft}$.; 


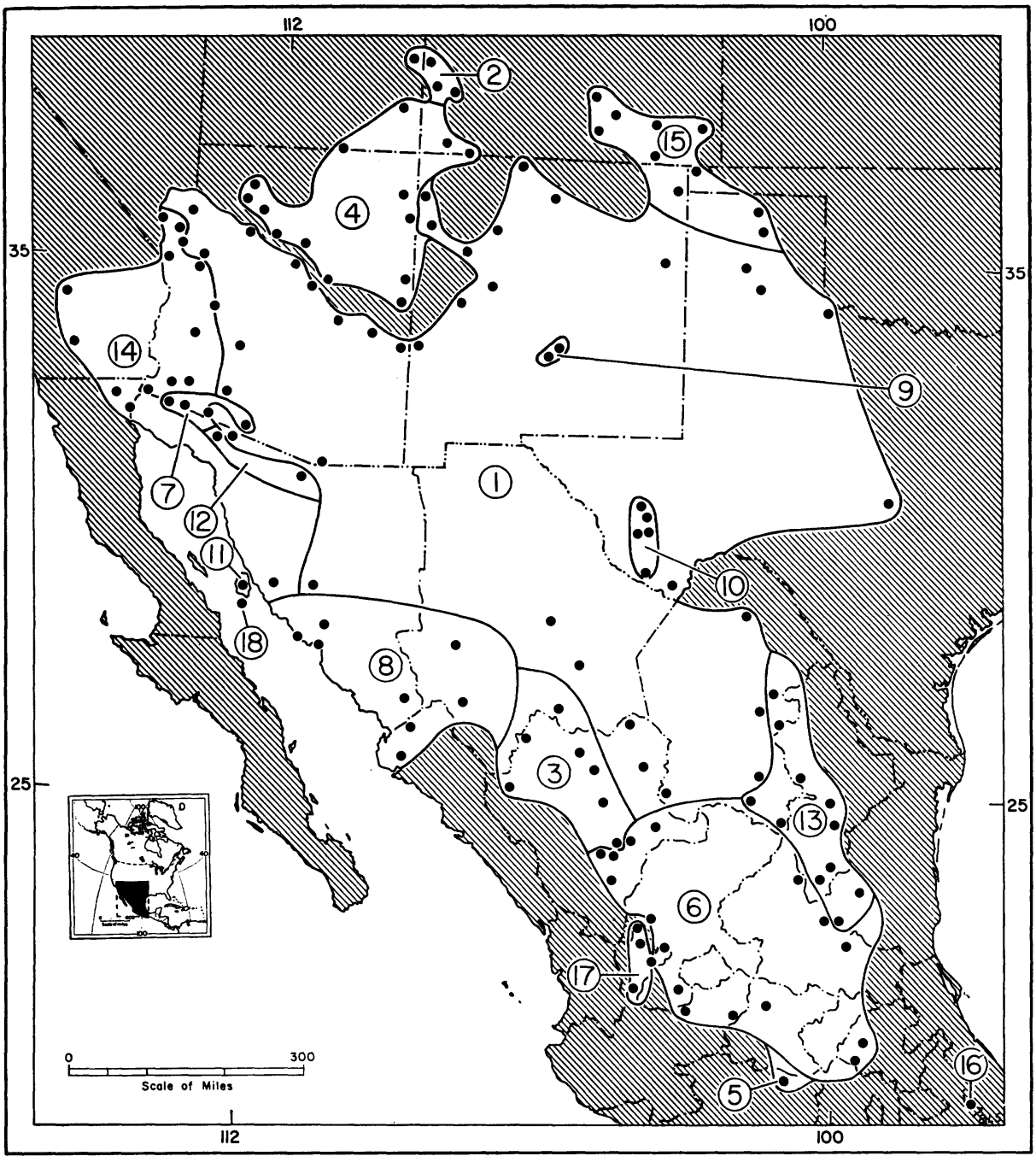

Fig. 4.-Geographic ranges of the species and subspecies of the Neotoma albigula-group. Numerals on the map correspond to those in the list of species and subspecies.
1. N. a. albigula
7. N. a. mearnsi
13. N. a. subsolana
2. N. a. brevicauda
8. N. a. melanura
14. N. a. venusta
3. N. a. durangae
9. N. a. melas
4. N. a. laplataensis
10. N. a. robusta
15. N. a. warreni
5. N. a. latifrons
11. N. a. seri
16. N. nelsoni
6. N. a. leucodon
12. N. a. sheldoni
17. N. palatina
18. N. varia

Seligman; Montezuma Well, $3500 \mathrm{ft}$; $7 \mathrm{mi}$. N Payson, $4500 \mathrm{ft}$.; Salt River, about 12 mi. N McMillenville, $3000 \mathrm{ft}$.; White River, Chiricahua Ranch, $4700 \mathrm{ft} ., 20 \mathrm{mi}$. NE Calva; San Francisco River, $13 \mathrm{mi}$. above Clifton, $4000 \mathrm{ft}$. New Mexico: Glenwood; Datil Mts.; Riley; San Rafael; Gallup; Canyon de Chelly; Grants; Cabezon. 
2. Neotoma albigula brevicauda Durrant, 1934. Marginal Records (Finley, 1958:291, 293).-Utah: type locality. Colorado: $1 \mathrm{mi}$. SW Gateway, $4600 \mathrm{ft}$.; Coventry $6800 \mathrm{ft}$.; Bedrock, $5150 \mathrm{ft}$.

3. Neotoma albigula durangae J. A. Allen, 1903. Marginal Reconds (Baker and Greer, 1962:127, unless otherwise noted).-Chihuahua: Parral (Hall and Kelson, 1959:686). Durango: $3 \mathrm{mi}$. E Las Nieves, $5400 \mathrm{ft}$.; $4 \mathrm{mi}$. NNE Boquilla, $6300 \mathrm{ft}$.; $7 \mathrm{mi}$. NNW La Zarca, $6000 \mathrm{ft} . ; 81 \frac{1}{2}$ mi. $N$ Alamillo, $5900 \mathrm{ft}$; $2.6 \mathrm{mi}$. S Alamillo, $4900 \mathrm{ft}$.; Mt. San Gabriel; La Ciénega de las Vacas; Arroyo de Bucy; Rancho Santuario.

4. Neotoma albigula laplataensis F. W. Miller, 1933. Marginal Records (Cockrum, 1961:194-195, unless otherwise indicated).- Utah: Recapture Canyon, $12 \mathrm{mi}$. N Blanding, $6000 \mathrm{ft}$. (Hall and Kelson, 1959:686). Colorado: Wetherill Mesa, Mesa Verde National Park (Douglas, 1967:322); type locality. Arizona: St. Michaels, $7000 \mathrm{ft}$.; St. Johns, 5800 $\mathrm{ft}$., $3 \mathrm{mi}$. SE Springerville; Turkey Creek, $3400 \mathrm{ft}$.; Canyon Padre; Winona, $6400 \mathrm{ft}$.; Red Lake; $12 \mathrm{mi}$. WSW Anita; Supai Canyon; Bass Camp, $6600 \mathrm{ft}$.; Rainbow Lodge, $6400 \mathrm{ft}$., Navajo Mtn.

5. Neotoma albigula latifrons Merriam, 1895 (as Neotoma latifrons). MARginal RecORDS (present paper).-Michoacán: Isla Palmitas; type locality.

6. Neotoma albigula leucodon Merriam, 1894 (synonyms, Neotoma montezumae Goldman, 1905, and Neotoma leucodon zacatecae Goldman, 1905). Marginal Records (present paper, unless otherwise indicated ).-Durango (Baker and Greer, 1962:127): Hda. Atotonilco, $6680 \mathrm{ft}$. San Luis Potosí (Dalquest, 1953:160): $6 \mathrm{~km} \mathrm{~S}$ Matehuala; Presa de Guadalupe; 3 mi. NW Tepeyac; 10 mi. NW Ciudad del Maíz. Hidalgo: Zimapán; Ixmiquilpán; Marqués. Guanajuato: La Quemada. Jalisco: $3 \mathrm{mi}$. E Unión de San Antonio, $6100 \mathrm{ft}$; $10 \mathrm{mi}$. NE Yahualica. Zacatecas: $3 \mathrm{mi}$. SW Jalpa. Jalisco: $3 \mathrm{mi}$. E Totatiche, $5600 \mathrm{ft}$.; La Mesa Maria de León, $7400 \mathrm{ft}$., $22^{\circ} 25^{\prime} \mathrm{N}, 103^{\circ} 24^{\prime} \mathrm{W}$. Zacatecas: Valparaiso. Durango (Baker and Greer, 1962:127, as N. a. zacatecae, unless otherwise indicated ): $16 \mathrm{mi}$. S, $29 \mathrm{mi}$. W Vicente Guerrero, $6675 \mathrm{ft}$.; $9 \mathrm{mi}$. N Durango; $1 \mathrm{mi}$. N Chorro; $26 \mathrm{mi}$. SW Yerbanís, $6725 \mathrm{ft}$. (Baker and Greer, 1962:127, as N. a. leucodon).

7. Neotoma albigula mearnsi Goldman, 1915. Marginal Records (Cockrum, 1961: 194).-Arizona: S of Wellton; $9 \mathrm{mi}$. E Papago Well, $1100 \mathrm{ft}$.; Alamo Canyon, Ajo Mts.; $26 \mathrm{mi}$. S Wellton, $500 \mathrm{ft}$.

8. Neotoma albigula melanura Merriam, 1894. Marginal Records (Hall and Kelson, 1959:688, unless otherwise indicated).-Sonora: type locality. Chihuahua: Mojarachic; Batopilas. Sinaloa: $3 \mathrm{mi}$. N, $1 \mathrm{mi}$. E San Miguel, $350 \mathrm{ft}$. (Jones et al., 1962:157); 21/2 mi. N El Fuerte (Ibid.). Sonora: Alamos; Batamotal; Bahía San Pedro.

9. Neotoma albigula melas Dice, 1929.

10. Neotoma albigula robusta Blair, 1939.

11. Neotoma albigula seri Townsend, 1912.

12. Neotoma albigula sheldoni Goldman, 1915.

13. Neotoma albigula subsolana Alvarez, Univ. Kansas Publ., Mus. Nat. Hist., 14:141, April 30, 1962, type from Miquihuana, $6400 \mathrm{ft}$., Tamaulipas. Marginal Reconds (Alvarez, 1962:143, unless otherwise indicated).-Coahuila: $9 \mathrm{mi}$. E Hermanas; Panuco, $3000 \mathrm{ft}$. Nuevo León: Santa Catarina (Hall and Kelson, 1959:686); Ojo de Agua (Ibid.); Iturbide, Sierra Madre Oriental, $5000 \mathrm{ft}$; $9 \mathrm{mi}$. S Aramberri, $3900 \mathrm{ft}$. Tamaulipas: Joya Verde, 35 km SW Cd. Victoria (on Jaumave Road), $3800 \mathrm{ft}$. (Alvarez, 1963:451); Jaumave (Hall and Kelson, 1959:686); $9 \mathrm{mi}$. SW Tula, $3900 \mathrm{ft}$. (Alvarez, 1963:451); Nicolás, $56 \mathrm{~km} \mathrm{NW}$ Tula, $5500 \mathrm{ft}$. (Ibid.). Nuevo León: Doctor Arroyo, $5800 \mathrm{ft}$. Coahuila: $8 \mathrm{mi}$. N La Ventura, $5500 \mathrm{ft}$.; north slope Sierra Guadalupe, $10 \mathrm{mi}$. S, $5 \mathrm{mi}$. W General Cepada, $6500 \mathrm{ft}$; $6 \mathrm{mi}$. E Hermanas.

14. Neotoma albigula venusta True, 1894 (synonyms, Neotoma cumulator Mearns, 1897, and Neotoma desertorum grandis Elliot, 1904). Marginal Records (Cockrum, 1961 : 195-196, unless otherwise indicated).-Arizona: Colorado R., $31 \mathrm{mi}$. N, 21/2 mi. W Camp 
Mohave; Mineral Park; Kingman; Congress Junction; Harquahala Mts., 71/2 mi. S Salome, $5000 \mathrm{ft}$.; Norton; Wellton; $4 \mathrm{mi}$. S Gadsden. Sonora: Costa Rica Ranch (Hall and Kelson, 1959:688). Baja California: Colonia Lerdo (Ibid.); E base Cocopah Mts. (Ibid.). California: Borrego Spring (Ibid.); Long Canyon, $29 \mathrm{mi}$. N, 191/2 mi. W Mecca (Rainey, 1965: 29). Arizona: Fort Mohave.

15. Neotoma albigula warreni Merriam, 1908. Marginal Records (Hall and Kelson, 1959:688, unless otherwise indicated).-Colorado: $2 \mathrm{mi}$. E Wetmore, $5700 \mathrm{ft}$.; junction Huerfano and Cucharas rivers; $3 \mathrm{mi}$. NW Highbee, $4300 \mathrm{ft}$; Two Buttes Peak, $4500 \mathrm{ft}$. Oklahoma: Regnier, $4500 \mathrm{ft}$. Texas (Cutter, 1959:449): $10 \mathrm{mi}$. S, $3 \mathrm{mi}$. W Gruver; $2 \mathrm{mi}$. S, $11 \mathrm{mi}$. E Pringle. New Mexico: Clayton. Colorado: $11 \mathrm{mi}$. N, $8 \mathrm{mi}$. E Branson, $5600 \mathrm{ft}$;; $9 \mathrm{mi}$. SW Walsenburg, $6600 \mathrm{ft}$.

16. Neotoma nelsoni Goldman, 1905.

17. Neotoma palatina Goldman, 1905. Marginal Records (present paper).--Jalisco: $10 \mathrm{mi}$. NE Huejuquilla, $6800 \mathrm{ft}$.; $1 \mathrm{mi}$. NW Mezquitic, $5000 \mathrm{ft}$; $3 \mathrm{mi}$. N Villa Guerrero, $5600 \mathrm{ft}$.; $3 \mathrm{mi}$. E Totatiche, $5600 \mathrm{ft}$.; $6 \mathrm{mi}$. ENE Bolaños, $5350 \mathrm{ft} . ; 4 \mathrm{mi}$. ENE Bolaños, $4400 \mathrm{ft}$.; $2 \mathrm{mi}$. E Bolaños, $3550 \mathrm{ft}$; type locality; $5 \mathrm{mi}$. NE Huejuquilla, $6200 \mathrm{ft}$.

18. Neotoma varia Burt, 1932.

\section{Peripheral Species and Unsolved Problems}

The three species Neotoma nelsoni, N. palatina, and $N$. varia (the last known to us by only the description) resemble Neotoma albigula morphologically more than they resemble any other species, and we infer from this that the three are genetically more closely related to $N$. albigula than to any other species. Two, $N$. nelsoni and $N$. varia, are geographic isolates, and all three are peripheral to the much larger geographic range of $N$. albigula. This arrangement of a polytypic species having peripheral species is a common arrangement as pointed out by several zoologists (for example, Mayr, 1966:80, 261, 386-393, 496, 526 , and 544 ).

Lest the reader conclude that the authors think, and lest others conclude, that little remains to be done with the systematics of the Neotoma albigula-group of woodrats as a means of elucidating their evolutionary history, we wish to emphasize that careful comparative study of all of the existing museum specimens probably would significantly alter the taxonomic arrangement suggested immediately above. Our arrangement, then, attempts to show our present understanding. One matter not touched on here is the intergradation of Neotoma albigula and Neotoma micropus in southeastern Colorado (see Finley, 1958: 302,315 ). Also, the results of the meeting of these same two species remain to be evaluated where they meet (and overlap geographically according to the literature as it now stands) farther south in Texas and on the tableland of México. [After our manuscript was transmitted ( 13 May 1969), Anderson, Univ. Kansas Mus. Nat. Hist. Misc. Publ., 51:25-50, 11 July 1969, published important information on the relationship of Neotoma albigula and N. micropus in Chihuahua. Also, he regarded the Río Conchos as the boundary between the two subspecies Neotoma a. albigula and N. a. durangae; thereby the range of $N$. $a$. durangae is extended northeastward to include the southern part of the geographic range of N. a. albigula shown on our map, Fig. 4.]

\section{ACKNOWLEDGMENTS}

We are grateful to Dr. Charles O. Handley, Jr., and associates in the United States National Museum (USNM) and to Dr. Richard H. Manville and his associates in the United States Biological Surveys Collection for making specimens available to us for comparison, and thank the Trustees of the Kansas University Endowment Association for financial assistance, from the Watkins Fund, with field work that yielded essential specimens from critical localities, and are likewise grateful to the National Science Foundation for financial assistance (GB-5909) with some phases of our work in the museum laboratory. 


\section{Literature Cited}

Alvarez, T. 1962. A new subspecies of wood rat (Neotoma) from northeastern Mexico. Univ. Kansas Publ., Mus. Nat. Hist., 14: 139-143.

- 1963. The Recent mammals of Tamaulipas, México. Univ. Kansas Publ., Mus. Nat. Hist., 14: 363-473.

Baker, R. H., AND J. K. Greer. 1962. Mammals of the Mexican state of Durango. Publ. Mus., Michigan State Univ., Biol. Ser., 2: 25-154.

Burt, W. H. 1960. Bacula of North American mammals. Misc. Publ. Mus. Zool., Univ. Michigan, 113: 1-75.

Cockrum, E. L. 1961. The Recent mammals of Arizona. The Univ. Arizona Press, Tucson, viii $+276 \mathrm{pp}$.

Cutter, W. L. 1959. The Warren wood rat in Texas. J. Mamm., 40: 448-449.

Dalquest, W. W. 1953. Mammals of the Mexican state of San Luis Potosí. Louisiana State Univ. Studies, Biol. Ser., 1: 1-229.

$\rightarrow$ - 1968. Mammals of north-central Texas. Southwestern Nat., 13: 13-21.

Douglas, C. L. 1967. New records of mammals from Mesa Verde National Park, Colorado. J. Mamm., 48:322-323.

FinLey, R. B. 1958. The wood rats of Colorado: distribution and ecology. Univ. Kansas Publ., Mus. Nat. Hist., 10: 213-552.

Goldman, E. A. 1905. Twelve new wood rats of the genus Neotoma. Proc. Biol. Soc. Washington, 18: 27-33.

1910. Revision of the wood rats of the genus Neotoma. N. Amer. Fauna, 31: $1-124$.

Hall, E. R., AND K. R. Kelson. 1959. The mammals of North America. The Ronald Press Co., New York, 2: viii + 547-1083 + 79 .

Jones, J. K., JR., T. Alvarez, AND M. R. LeE. 1962. Noteworthy mammals from Sinaloa, Mexico. Univ. Kansas Publ., Mus. Nat. Hist., 14: 147-159.

MAYr, E. 1966. Animal speciation and evolution. Harvard University Press, xiv $+797 \mathrm{pp}$.

Merriam, C. H. 1894. Abstract of a study of the American wood rats, with description of fourteen new species and subspecies of the genus Neotoma. Proc. Biol. Soc. Washington, 9: 117-128.

Rainey, D. G. 1965. Observations on the distribution and ecology of white-throated wood rat in California. Bull. Southern California Acad. Sci., 64: 27-42.

Museum of Natural History, The University of Kansas, Lawrence, 66044. Accepted 2 April 1970. 